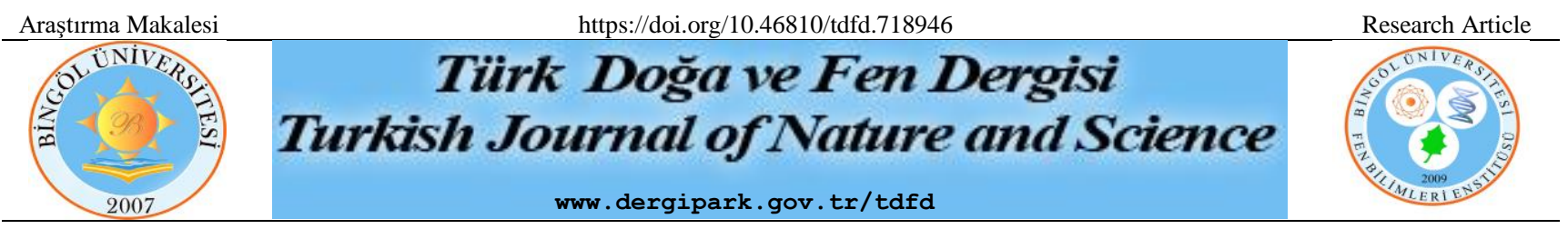

\title{
Geçici Stres Dönemi ve Sonrasında Biber Fidelerinin Mikro Element Alım Performansı
}

\author{
Hacı Yusuf KADAN ${ }^{1}$, Özlem ÜZAL ${ }^{2 *}$, Fikret YAȘAR ${ }^{2}$ \\ ${ }^{1}$ Van Yüzüncü Yıl Üniversitesi, Fen Bilimleri Enstitüsü, Van, Türkiye \\ ${ }^{2}$ Van Yüzüncü Yıll Üniversitesi, Ziraat Fakültesi, Bahçe Bitkileri Bölümü, Van, Türkiye \\ Hac1 Yusuf KADAN ORCID No: 0000-0003-1701-6378 \\ Özlem ÜZAL ORCID No: 0000-0002-1538-820X \\ Fikret YAŞAR ORCID No:0000-0001-6598-8580
}

*Sorumlu yazar: ozlemuzal@yyu.edu.tr

(Alınış: 12.04.2020, Kabul: 01.10.2020, Online Yayınlanma: 23.10.2020)

\begin{abstract}
Anahtar
Kelimeler

Biber,

Capsicum

annum L.,

Capsicum

frutescens L.,

Stres sonrasi,

Tuz
\end{abstract}

Öz: Yapılan bu çalışmada; geçici tuz stresi döneminde ve sonrasında Çarliston (Capsicum annuum L./ tatlı) ve Acı çiçek (Capsicum frutescens L. /acı) biber bitkisindeki metabolik olayların nasıl etkilendiğini açıklığa kavuşturmak, bitkilerin geçici stres dönemi ve sonrasında mikro element alımında oluşan değişikliklerin nasıl olduğunu belirlemek amaçlanmıştır. Bu amaçla 4-5 gerçek yaprağa sahip olan fidelere tuz uygulamaları yapılmıştır. Tuz uygulanmadan önce (0.gün) bitki örnekleri alınarak, tuz uygulanacak fideler için besin çözeltisine $50 \mathrm{mM} \mathrm{NaCl}$ ilave edilmiştir. Geçici tuz stresi dönemi ve geçici stres sonrası dönemlerde (10. ve 20. günde) örnek alma işlemi yapılmıştır. Bitkilerin, toplam bitki yaş ağırlığı ile yaprak kısımlarında bazı mikro element içerikleri belirlenmiştir. Yapılan ölçümler sonucunda tuz stresinin her iki biber çeşidinin de bitki gelişimi üzerine olumsuz etkisinin olduğu görülmüştür. Geçici stres sonrası dönemin 20. gününde ise özellikle Çarliston biber çeşidinde toplam bitki yaş ağırlıklarının kontrole (kontrol:109.98 g tuz: $88.20 \mathrm{~g}$ ) en yakın değerler aldığı belirlenmiştir. Acı çiçek biber çeşidi ise metabolik aktiviteyi kontrol altında tutabilmek için bitki büyümesini sınırlandırarak bitkiyi kontrol edebilecek seviyede tutmuş olabileceği kanaatine varılmıştır. Ayrıca her iki biber çeşidinin yapraklarında tuz uygulama döneminin 20.gününde Fe (Çarliston kontrol: 29.39, tuz: 35.44; Acı çiçek kontrol: 26.54, tuz: 29.39 $\mu \mathrm{g}$ mg T.A.), Zn (Çarliston kontrol: 4.00, tuz: 5.4; Ac1 çiçek kontrol: 3.92, tuz: $5.01 \mu \mathrm{g}$ mg T.A.) ve Mn (Çarliston kontrol: 19.14, tuz: 37.5; Ac1 çiçek kontrol: 23.29, tuz: $26.73 \mu \mathrm{g}$ mg T.A.) konsantrasyonlarında artışların olduğu belirlenmiştir.

\section{Micro Element Uptake Performance of Pepper Seedlings in Temporary Stress Period and Post-Stress Period}

Keywords
Capsicum
annum L.,
Micro
element,
Pepper,
Capsicum
frutescens L.,
post-stress

\begin{abstract}
In this study; It is aimed to clarify how the metabolic events in Carliston (Capsicum annиит L./sweet.) and Aci cicek (Capsicum frutescens L./hot) pepper plants are affected under salt stress and post- stress process and to determine the changes in the intake of micro elements in salt stress and post-stress process of plants. For this purpose, salt application was started on the seedlings having 4-5 real leaves. Before salt application (day 0) plant samples were taken, $50 \mathrm{mM}$ $\mathrm{NaCl}$ was added into nutrient solution for seedlings to be applied salt stress. Sampling was performed on the $10^{\text {th }}$ and $20^{\text {th }}$ days of the salt application period and post- stress period. The total plant weight of the plants was measured and some micro element contents in the leaves were determined. As a result of the measurements, it was observed that salt stress had a negative effect on plant growth in both pepper cultivars. In the post- stress process on the $20^{\text {th }}$ day, it was determined that the total plant wet weights, especially in Carliston pepper variety, were closest to control (control:109.98 g, salt: $88.20 \mathrm{~g}$ ). In order to keep the metabolic activity under control, it was concluded that the hot pepper variety could be kept at a level that could control the plant by limiting plant growth. In addition, it was determined that Fe (Carliston control: 29.39, salt: 35.44; aci cicek control: 26.54, salt: $29.39 \mu \mathrm{g} \mathrm{mg} \mathrm{F.W.),} \mathrm{Zn} \mathrm{(Carliston} \mathrm{control:} \mathrm{4.00,} \mathrm{salt:} \mathrm{5.4;} \mathrm{aci} \mathrm{cicek} \mathrm{control:}$ 3.92, salt: $5.01 \mu \mathrm{g} \mathrm{mg} \mathrm{F.W.)} \mathrm{and} \mathrm{Mn} \mathrm{(Carliston} \mathrm{control:} \mathrm{19.14,} \mathrm{salt:} \mathrm{37.5;} \mathrm{Aci} \mathrm{cicek} \mathrm{control:} \mathrm{23.29,}$ salt: $26.73 \mu \mathrm{g} \mathrm{mg} \mathrm{F.W.)} \mathrm{concentrations,} \mathrm{were} \mathrm{increased} \mathrm{during} \mathrm{the} \mathrm{salt} \mathrm{application} \mathrm{period.}$
\end{abstract}




\section{GíRiş}

Tuz stresi, bitkilerin yetiştirildikleri ortamda, büyüme ve gelişmelerini olumsuz etkileyecek miktarda çözünmüş tuzların bulunması sonucu ortaya çıkmaktadır [1]. Toprak tuzluluğuna sebep olan bileşikler genelde klorürler, sülfatlar, karbonatlar, bikarbonatlar ve boratlardır. Ancak doğada en çok rastlanılan tuz formu sodyum klorür $(\mathrm{NaCl})$ 'dür [2, 3, 4].

Sularda ve toprakta tuz konsantrasyonunun artmasıyla bitkinin topraktan su alımı güçleşmekte, bitkinin yaşamı için hasar verici etkilere neden olmaktadır. İyon dengesi, su durumu, mineral beslenme, stomatal hareketler, fotosentez etkinliği, karbon dağılımı ve kullanımındaki değişiklikleri içeren çeşitli fizyolojik olaylar sonucunda bitki büyüme ve gelişimi yavaşlamaktadır [5,6]. İyon dengesizliğinin ve köklerde hücre zarı geçirgenliğinin bozulmasının bitkinin beslenme rejimini etkileyerek, metabolik olaylarda kullanılan temel bazı elementlerin alımını engellediği, bunun sonucunda da bazı fizyolojik sorunların ortaya çıkacağı ileri sürülmektedir [7]. İyon dengesizliği ile ilgili benzer bir açıklamada Bohra ve Döffling [8]; Yaşar, [9]; Yasar ve ark., [10]; Yildiz ve ark., [11]; Üzal ve Yıldız, [12] tarafindan yapılmıştır. Bu araştırıcılar tuz stresinde bitkinin kök bölgesinde iyon dengesinin bozulduğunu; artan miktardaki sodyum alımının diğer mineral maddelerinin alımı ile rekabete girerek beslenme noksanlığına yol açtığını bildirmişlerdir. Levitt [13]'e göre tuz stresinden kaynaklanan iyon toksisitesi birincil stres, su stresi ve mineral beslenme ile ilgili olan etkiler ise ikincil stres olarak tanımlanmıștır.

Bitkisel üretimde tuzluluğun zararlı etkisi azaltmak için; tuzlu toprakların islah edilmesi, tuzlu sulama sularının iyileştirilmesi, yetiștiricilik sırasında özel tekniklerin kullanılması, tuza tolerant genotiplerin seçimi gibi uygulamalar yapılması gereken hususlardır $[9,10,14$, $15,16]$.

Bitkilerde birçok metabolik olayı olumsuz yönde etkileyen ve özellikle kültür bitkilerinde ürün kalitesi ve verimi düşüren önemli abiyotik faktörlerden biri olan tuz stresi, gerek açıkta ve gerekse örtü altı yetiştiricilikte önemli payı olan biber bitkisini olumsuz etkilemektedir. $\mathrm{Bu}$ olumsuz şartlardan dolayı ürün ve kalite kayıpları da ciddi boyutlara ulaşabilmektedir. $\mathrm{Bu}$ olumsuzlukları ortadan kaldırmanın en önemli ve en kesin yoluda tuzluluğa toleranslı bitki tür ve çeşitlerini geliştirmek ve tuzluluğun olumsuz etkilerini giderici uygulamalar yapmaktır. Ancak böyle toleranslı tür ve çeşitleri geliştirebilmek için; özellikle önce bitkinin stres mekanizmasını çok iyi aydınlatmak gerekmektedir. Tuzluluğun bitkilerin mikro besin kompozisyonunu nasıl etkilediği konusu tam olarak açık değildir. Biber bitkisinde tuz stresi sonrası geri kazanım sürecindeki içsel mekanizmalar ile ilgili yapılan bir araştırmaya rastlanmamış olup, bu yönüyle ele alındığında; çalışma bu konuda ilk olması nedeniyle özgündür. Bu çalışmada tuz stresi altında kalan bitkilerin stres döneminde ve sonrasında bitki toplam ağırlığında ve mikro element alımında nasıl bir değişikliğin olduğu, bitkilerin hangi uyum mekanizmaları geliştirdiğini anlamak amaçlanmıştır.

\section{MATERYAL VE METOT}

Normal atmosferin sağlandığı split klimalı iklim odasında ve su kültüründe yürütülen çalışmada Çarliston ve Acı çiçek biber çeşitleri kullanılmıştır. Biber tohumları, pomza ve torf doldurulmuş alt yüzeyi $0,5 \mathrm{~cm}$ çapında toplam 9 adet deliğe sahip çimlendirme kaplarına 100'er adet tohum ekilip sonra çeşme suyu ile sulanmıştır. Çimlendirme kapları, $25 \pm 1{ }^{\circ} \mathrm{C}$ sıcaklık \%70 neme sahip iklim odasına yerleştirilerek, çeşme suyu ile sulanmaya devam edilmiştir. Kotiledon yaprakları yatay duruma gelen ve ilk gerçek yaprakları görülmeye başlayan fidelerde sulama Hoagland besin çözeltisiyle [17] yapılmaya başlanmıştır. Kullanılan besin çözeltisinin içeriği Tablo 1' de verilmiştir.

Tablo 1. Kullanılan besin çözeltisinin içeriği

\begin{tabular}{|l|l|l|l|}
\hline Makro elementler & $\mathrm{g} / \mathrm{lt}$ & Mikro elementler & $\mathrm{g} / \mathrm{lt}$ \\
\hline $\mathrm{Ca}\left(\mathrm{NO}_{3}\right)_{2} .4 \mathrm{H}_{2} \mathrm{O}$ & 1.180 & $\mathrm{C}_{6} \mathrm{H}_{5} \mathrm{FeO}_{7} .5 \mathrm{H}_{2} \mathrm{O}$ & 0.02 \\
\hline $\mathrm{KNO}_{3}$ & 0.252 & $\mathrm{Mn} \mathrm{Cl}_{2}$ & 0.00072 \\
\hline $\mathrm{KH}_{2} \mathrm{PO}_{4}$ & 0.136 & $\mathrm{H}_{3} \mathrm{BO}_{3}$ & 0.00116 \\
\hline $\mathrm{MgSO}_{4}$ & 0.246 & $\mathrm{ZnCl}_{2}$ & 0.000048 \\
\hline & & $\mathrm{CuCl}_{2} 2 \mathrm{H}_{2} \mathrm{O}$ & 0.00004 \\
\hline
\end{tabular}

$\mathrm{Bu}$ ortamda 2. gerçek yaprakları oluşan fideler, içinde besin çözeltisi doldurulmuş $25 \times 25 \times 18 \mathrm{~cm}$ boyutlarındaki plastik küvetlerde bitki kökleri besin çözeltisinde olacak şekilde yerleştirilerek su kültürüne alınmıștır. Havalandırma işlemi, akvaryum pompası yoluyla yapılmıştır. Fideler iki hafta süreyle su kültüründe büyütülerek, 4-5 gerçek yaprağa sahip iken, tuz uygulamalarına başlanmıştır. Tuz uygulanmadan önce bitki örnekleri alınarak, tuz uygulamaları yapılacak fidelerin bulunduğu kaplardaki besin çözeltisine $50 \mathrm{mM}$ tuz konsantrasyonunu sağlayacak $\mathrm{NaCl}$ ilave edilmiştir. Her hafta çözeltiler tazelenmiştir. Bu yineleme esnasında çözeltinin aynı tuz konsantrasyonda olmasına dikkat edilmiştir. Tuz uygulamasının 10. ve 20. gününde örnek alma işlemi yapılmış, daha sonra tuz uygulaması kesilip, bitkiler, içinde tuz olmayan hogland besin çözeltisinde yetiştirilmeye devam edilerek geçici stres sonrası sürecine alınmıştır. Bu süreçte ise örnek alma işlemi 10. ve 20. günde olmak üzere iki defada yapılmıştır. Bitkilerin, toplam yaş ağırlığı $(\mathrm{g})$, bazı mikro element (Fe, $\mathrm{Zn}, \mathrm{Cu}$ ve $\mathrm{Mn}$ ) içerikleri belirlenmiştir.

\subsection{Toplam Bitki Yaş Ağırlığının Belirlenmesi}

Toplam bitki yaş ağırlığı üç tekerrürlü olarak 1/10.000' lik hassas dijital terazi ile ölçülmüştür.

\subsection{Mineral Element Analizleri}

Bitkilerin orta bölümündeki yaprak kısımlarından alınan bitki örnekleri $-84{ }^{\circ} \mathrm{C}$ 'deki derin dondurucuda saklanmıştır. Mikro element analizleri için yaş yakma metoduna göre ekstraksiyon hazırlanmış ve ekstraktlarda, mikro elementlerden $\mathrm{Fe}, \mathrm{Cu}, \mathrm{Zn}$ ve $\mathrm{Mn}$ içerikleri ise, Kacar [18]'a göre Atomik Absorbsiyon 
cihazında okunmuştur. Ölçümler sonunda, yaş yaprak örneğindeki mikro element miktarı $\mu \mathrm{g} \mathrm{mg}^{-1}$ taze ağırlık şeklinde tayin edilmiştir [19].

\section{3. İstatistiksel Analizler}

Çalışmanın sonucunda elde edilen verilerin değerlendirilmesi için Statgraphics istatistik analiz paket programında varyans analizine tabi tutulmuştur. İstatistiksel olarak önemli bulunan deneme konular1 \%5 önem seviyesinde Duncan testi ile gruplandırılmıştır.

\section{BULGULAR}

\subsection{Bitki Toplam Yaş Ağırlığındaki Değişimler}

Tuz uygulaması dönemi ile stres sonrası dönemlerde, periyodik olarak alınan çarliston ve acı çiçek biber çeşidinin toplam yaş ağırlıklarında gerek kontrol bitkilerinde ve gerekse tuz uygulanan bitkilerde dönemsel olarak istatistiksel anlamda önemli farklılıkların olduğu belirlenmiştir (Tablo 2).

Tablo 2. Tuz uygulaması öncesi (0. gün), tuz uygulama dönemi ve geçici stres sonrası dönemde periyodik olarak belirlenen toplam bitki yaș ağırlıkları (g)

\begin{tabular}{|c|c|c|c|c|c|c|c|}
\hline \multirow[t]{2}{*}{ DÖNEM } & \multirow{2}{*}{ PERIYYOT } & \multicolumn{2}{|c|}{ ÇARLİSTON } & \multirow{2}{*}{$\begin{array}{c}\mathrm{P} \\
\text { DEĞ. }\end{array}$} & \multicolumn{2}{|c|}{ ACI ÇİÇEK } & \multirow{2}{*}{$\begin{array}{c}\mathrm{P} \\
\text { DEĞ. }\end{array}$} \\
\hline & & KONTROL & $\mathrm{NaCl}$ & & KONTROL & $\mathrm{NaCl}$ & \\
\hline $\begin{array}{l}\text { STRES } \\
\text { ÖNCESİ }\end{array}$ & 0. Gün & $6,19 \pm 0,1 \mathrm{E}$ & $6,19 \pm 0,1 \mathrm{E}$ & - & $4,61 \pm 0,38 \mathrm{D}$ & $4,61 \pm 0,38 \mathrm{E}$ & - \\
\hline \multirow{2}{*}{$\begin{array}{l}\text { GEÇİCİ STRES } \\
\text { UYGULAMA } \\
\text { DÖNEMİ }\end{array}$} & 10. GÜN & $24,45 \pm 6,21 \mathrm{D}$ & $16,11 \pm 1,3 \mathrm{D}$ & 0,0851 & $10,92 \pm 2,93 \mathrm{C}$ & $7,83 \pm 0,21 \mathrm{D}$ & 0,1427 \\
\hline & 20. GÜN & $40,52 \pm 2,22 \mathrm{C}$ & $34,69 \pm 4,35 \mathrm{C}$ & 0,1074 & $48,89 \pm 0,43 \mathrm{~B}$ a & $35,44 \pm 0,43 \mathrm{C} \mathrm{b}$ & 0,0000 \\
\hline \multirow{2}{*}{$\begin{array}{l}\text { GEÇİCİ STRES } \\
\text { SONRASI } \\
\text { DÖNEM }\end{array}$} & 10. GÜN & $80,97 \pm 0,55 \mathrm{~B}$ a & $46,02 \pm 1,50 \mathrm{~B} \mathrm{~b}$ & 0,0000 & $79,54 \pm 2,45 \mathrm{~A} \mathrm{a}$ & $42,58 \pm 2,55 \mathrm{~B} \mathrm{~b}$ & 0,0001 \\
\hline & 20. GÜN & $109,98 \pm 3,19 \mathrm{~A} \mathrm{a}$ & $88,28 \pm 5,27 \mathrm{~A} \mathrm{~b}$ & 0,0037 & $79,15 \pm 1,58 \mathrm{~A}$ a & $52,66 \pm 1,71 \mathrm{~A} \mathrm{~b}$ & 0,0000 \\
\hline \multicolumn{2}{|c|}{ P DEĞERİ } & 0,0000 & 0,0000 & - & 0,0000 & 0,0000 & - \\
\hline
\end{tabular}

Aynı sütunda aynı büyük harfi alan ortalamalar arasındaki fark $\mathrm{P} \leq 0.05$ 'e göre önemsizdir. Aynı satırda aynı çeşidin aynı küçük harfi alan ortalamalar arasındaki fark $\mathrm{P} \leq 0.05$ 'e göre önemsizdir

Çarliston biber çeşidinin kontrol bitkilerinde dönemler boyunca bitkilerin toplam ağırlıklarında artışların olduğu tespit edilmiştir. Çarliston biber çeşidinin tuz uygulanan bitkilerinde geçici stres sonrası dönemin 10 . ve 20 . gününde toplam ağırlıklarında önemli ölçüde artışın olduğu belirlenmiştir. Geçici stres sonrası dönemin 10 . gününde 46,02 grama ulaşan bitki toplam ağırlığının aynı dönemin 20. gününde ise yaklaşık iki katı bir gelişim gösterip 88,28 grama ulaştığ 1 görülmüştür. Ac1 çiçek biber çeşidinde tuz uygulanan bitkilerin toplam ağırlıkları gerek tuz uygulama döneminde ve gerekse geçici stres sonrası dönemde önemli ölçüde arttığ1 dikkati çekmektedir. Uygulamalar karşılaştırıldığında, çarliston biber çeşidinde geçici stres sonrası dönemin 10. ve 20. gününde kontrol bitkileri ile tuz uygulaması yapılan bitkilerin toplam ağırlıklarındaki farklılıklar istatistiki olarak önemli bulunmuştur. Ac1 biber çeşidinde ise tuz uygulama döneminin 20. gün sonunda kontrol ile tuz uygulaması arasında toplam ağırlıkları bakımından istatiksel farklılıklar önemli bulunmuştur. Kontrol bitkilerinde 48,89 g olan toplam ağırlık, tuz uygulanan bitkilerde $35,44 \mathrm{~g}$ olarak belirlenmiştir. Geçici stres sonrası döneminin 10. ve 20. gününde toplam ağırlıkları bakımından önemli istatiksel farklılıkların olduğu tespit edilmiştir. Aynı dönemin 10. gününde kontrol bitkilerinin toplam ağırlıkları 79,54 g iken tuz uygulanan bitkilerde $42,58 \mathrm{~g}$ değerine düşmüştür. Geçici stres sonrası dönemin 20. gününde ise tuz uygulanan bitkilerin toplam ağırlıklarının arttığı ve 56,55 grama ulaştığı dikkati çekmektedir.

\subsection{Bitki Yapraklarında Belirlenen Bazı Mikro Element Miktarları}

\subsubsection{Yapraklardaki Fe iyonu miktarında meydana gelen değişimler}

Dönemler boyunca periyodik olarak alınan bitkilerin yapraklarında belirlenen demir miktarları Tablo 3.'de verilmiştir.

Çarliston ve acı çiçek biber çeşidinin gerek kontrol bitkilerinde ve gerekse tuz uygulanan bitkilerin yapraklarında belirlenen $\mathrm{Fe}$ içeriklerinin dönemsel olarak istatistiksel anlamda önemli farklılıkların olduğu belirlenmiştir. Çarliston biber çeşidinin tuz uygulanan bitkilerinde özellikle uygulama döneminin 20. gününde Fe miktarlarında düşüşün olduğu fakat bunun istatiksel olarak önemli olmadığı tespit edilmiştir ve geçici stres sonrası dönemin 10 . ve 20. gününde de $\mathrm{Fe}$ miktarlarındaki istatiksel farklığın önemli olmadığ belirlenmiştir. Acı çiçek biber çeşidinin tuz uygulanan bitkilerinde uygulama döneminde demir miktarlarında önemli düşüşlerin olduğu tespit edilmiştir. Acı biber çeşidinde istatiksel olarak en önemli farklılığın geçici stres sonras1 dönemin 20. gününde olduğu tespit edilmiştir. Uygulamalar karşılaştırıldığında, çarliston biber çeşidi tuz uygulamasının 20. gününde kontrol bitkileri ile tuz uygulaması yapılan bitkilerin yapraklarında ki demir miktarları istatistiki olarak önemsiz bulunmuştur. 
Tablo 3. Tuz uygulaması öncesi (0. gün), tuz uygulama dönemi ve geçici stres sonrası dönemde periyodik olarak alınan biber bitkilerinin yapraklarda ölçülen demir miktarları ( $\mu \mathrm{g} \mathrm{mg}^{-1}$ T.A.)

\begin{tabular}{|c|c|c|c|c|c|c|c|}
\hline \multirow[b]{2}{*}{ DÖNEM } & \multirow{2}{*}{ PERIYYT } & \multicolumn{2}{|c|}{ ÇARLİSTON } & \multirow{2}{*}{ P DEĞ. } & \multicolumn{2}{|c|}{ ACI ÇİÇEK } & \multirow{2}{*}{$\begin{array}{c}\mathrm{P} \\
\text { DEĞ. }\end{array}$} \\
\hline & & KONTROL & $\mathrm{NaCl}$ & & KONTROL & $\mathrm{NaCl}$ & \\
\hline STRES ÖNCESİ & $0 . G \mathrm{G} N$ & $33,23 \pm 5,73 \mathrm{~B}$ & $33,23 \pm 5,73 \mathrm{~B}$ & & $36,81 \pm 9,38 \mathrm{~B}$ & $36,81 \pm 9,38 \mathrm{~A}$ & - \\
\hline \multirow{2}{*}{$\begin{array}{l}\text { GEÇİCI STRES } \\
\text { UYGULAMA } \\
\text { DÖNEMİ }\end{array}$} & 10. GÜN & $35,00 \pm 5,93 \mathrm{~B} \mathrm{~b}$ & $55,14 \pm 19,68 \mathrm{~A} \mathrm{a}$ & 0,1651 & $73,75 \pm 13,89 \mathrm{~A} \mathrm{a}$ & $29,08 \pm 8,55 \mathrm{AB} b$ & 0,0090 \\
\hline & 20. GÜN & $29,39 \pm 7,74 \mathrm{~B}$ & $35,44 \pm 14,22 \mathrm{AB}$ & 0,5526 & $26,54 \pm 4,59$ В & $29,39 \pm 10,4 \mathrm{AB}$ & 0,6868 \\
\hline \multirow{2}{*}{$\begin{array}{l}\text { GEÇİĊ STRES } \\
\text { SONRASI } \\
\text { DÖNEM }\end{array}$} & 10. GÜN & $27,11 \pm 3,14 \mathrm{~B}$ & $27,18 \pm 1,89 \mathrm{~B}$ & 0,9729 & $36,64 \pm 17,7 \mathrm{~B} \mathrm{a}$ & $25,47 \pm 2,85 \mathrm{AB} \mathrm{b}$ & 0,3431 \\
\hline & 20. GÜN & $54,69 \pm 6,85 \mathrm{~A} \mathrm{a}$ & $32,03 \pm 7,54 \mathrm{~B} \mathrm{~b}$ & 0,0183 & $31,36 \pm 4,87 \mathrm{~B} \mathrm{a}$ & $22,48 \pm 2,48 \mathrm{C} \mathrm{b}$ & 0,0483 \\
\hline \multicolumn{2}{|c|}{ P DEĞERİ } & 0,0018 & 0,1042 & & 0,0033 & 0,2678 & \\
\hline
\end{tabular}

Aynı sütunda aynı büyük harfi alan ortalamalar arasındaki fark $\mathrm{P} \leq 0.05$ 'e göre önemsizdir. Aynı satırda aynı çeşidin aynı küçük harfi alan ortalamalar arasındaki fark $\mathrm{P} \leq 0.05$ 'e göre önemsizdir.

Ancak geçici stres sonrası dönemin 20. gününde demir miktarları bakımından farklılıkların önemli olduğu dikkati çekmektedir. Acı biber çeşidinde dönemler karşılaştırılma yapıldığında demir miktarlarında istatiksel olarak en önemli farklılı̆̆ın uygulama döneminin 10. gününde ve geçici stres sonrası dönemin 20. gününde olduğu tespit edilmiştir.

\subsubsection{Yapraklardaki $\mathrm{Cu}$ iyonu miktarında meydana gelen değişimler}

Dönemler boyunca periyodik olarak alınan bitkilerin yapraklarında belirlenen bakır miktarları Tablo 4.'de verilmiştir.

Tablo 4. Tuz uygulaması öncesi (0. gün), tuz uygulama dönemi ve geçici stres sonrası dönemde periyodik olarak alınan biber bitkilerinin yapraklarında ölçülen bakır miktarları $\left(\mu \mathrm{g} \mathrm{mg}^{-1} \mathrm{~T} . \mathrm{A}.\right)$

\begin{tabular}{|c|c|c|c|c|c|c|c|}
\hline \multirow[t]{2}{*}{ DÖNEM } & \multirow{2}{*}{ PERIYYOT } & \multicolumn{2}{|c|}{ ÇARLİSTON } & \multirow{2}{*}{ P DEĞ. } & \multicolumn{2}{|c|}{ ACI ÇIÇEK } & \multirow{2}{*}{ P DEĞ. } \\
\hline & & KONTROL & $\mathrm{NaCl}$ & & KONTROL & $\mathrm{NaCl}$ & \\
\hline STRES ÖNCESİ & 0.GÜN & $1,62 \pm 0,39 \mathrm{BC}$ & $1,62 \pm 0,39 \mathrm{BC}$ & - & $2,27 \pm 0,32 \mathrm{AB}$ & $2,27 \pm 0,32 \mathrm{~A}$ & - \\
\hline \multirow{2}{*}{$\begin{array}{l}\text { GEÇİCI STRES } \\
\text { UYGULAMA } \\
\text { DÖNEMİ }\end{array}$} & 10. GÜN & $3,00 \pm 0,13 \mathrm{~A} \mathrm{a}$ & $2,28 \pm 0,32 \mathrm{~A} \mathrm{~b}$ & 0,0234 & $2,52 \pm 0,63 \mathrm{~A}$ & $2,05 \pm 0,22 \mathrm{AB}$ & 0,2951 \\
\hline & 20. GÜN & $2,00 \pm 0,22 \mathrm{Ba}$ & $1,26 \pm 0,52 \mathrm{Bb}$ & 0,0880 & $1,11 \pm 0,22 \mathrm{C}$ & $1,19 \pm 0,35 \mathrm{C}$ & 0,7589 \\
\hline \multirow{2}{*}{$\begin{array}{l}\text { GEÇİCİ STRES } \\
\text { SONRASI } \\
\text { DÖNEM }\end{array}$} & 10. GÜN & $1,82 \pm 0,19 \mathrm{BC} \mathrm{a}$ & $1,20 \pm 0,31 \mathrm{~B} \mathrm{~b}$ & 0,0438 & $2,03 \pm 0,17 \mathrm{AB}$ a & $1,25 \pm 0,72 \mathrm{BC} \mathrm{b}$ & 0,1465 \\
\hline & 20. GÜN & $1,35 \pm 0,42 \mathrm{C}$ & $1,56 \pm 0,23 \mathrm{~B}$ & 0,4891 & $1,59 \pm 0,25 \mathrm{BC}$ & $1,82 \pm 0,32$ A-C & 0,3982 \\
\hline \multicolumn{2}{|c|}{ P DEĞERİ } & 0,0005 & 0,0339 & & 0,0055 & 0,0399 & \\
\hline
\end{tabular}

Aynı sütunda aynı büyük harfi alan ortalamalar arasındaki fark $\mathrm{P} \leq 0.05$ 'e göre önemsizdir. Aynı satırda aynı çeșidin aynı küçük harfi alan ortalamalar arasındaki fark $\mathrm{P} \leq 0.05$ 'e göre önemsizdir.

Çarliston ve acı çiçek biber çeşidinin gerek kontrol bitkilerinde ve gerekse tuz uygulanan bitkilerin yapraklarında belirlenen bakır içeriklerinin dönemsel olarak istatistiksel anlamda önemli farklılıkların olduğu belirlenmiştir. Çarliston biber çeşidinin tuz uygulanan bitkilerinde özellikle uygulama döneminin 20. gününde düşüşün olduğu ve bunun istatiksel olarak önemli olduğu tespit edilmiştir ve geçici stres sonrası dönemin 10 . ve 20. gününde ise bakır miktarlarında ki istatiksel farklığın önemli olmadığı belirlenmiştir. Acı çiçek biber çeşidinin tuz uygulanan bitkilerinde bakır miktarlarında önemli düşüşlerin olduğu tespit edilmiştir. Acı biber çeşidinde istatiksel olarak en önemli farklılığın uygulama döneminde tespit edilmiştir. Uygulamalar karşılaştırıldığında, çarliston biber çeşidi tuz uygulamasının 20. gününde kontrol bitkileri ile tuz uygulaması yapılan bitkilerin yapraklarındaki bakır miktarları istatistiki olarak önemsiz bulunmuştur. Fakat tuz uygulama dönemi ve geçici stres sonrası dönemlerinin 10. günündeki bakır miktarlarındaki farklılıklar istatiksel olarak önemli olduğu dikkati çekmektedir. Ac1 biber çeşidinde uygulamalar arası karşılaştırılma yapıldığında bakır miktarlarında istatiksel olarak önemli farklılıkların olmadığı tespit edilmiştir.

\subsubsection{Yapraklardaki Zn iyonu miktarında meydana gelen değişimler}

Dönemler boyunca periyodik olarak alınan bitkilerin yapraklarında belirlenen çinko miktarları Tablo 5. 'de verilmiştir.

Çarliston ve acı çiçek biber çeşidinin gerek kontrol bitkilerinde ve gerekse tuz uygulanan bitkilerin yapraklarında belirlenen çinko içeriklerinin dönemsel olarak istatistiksel anlamda önemli farklılıkların olduğu belirlenmiştir. Çarliston biber çeşidinin tuz uygulanan bitkilerinde özellikle uygulama döneminin 20. gününde Zn miktarında düşüşün olduğu fakat bunun istatiksel olarak önemli olmadığı tespit edilmiştir ve geçici stres sonrası dönemin 10 . ve 20 . gününde ise çinko miktarlarındaki istatiksel farklığın önemli olmadığı belirlenmiştir. Acı çiçek biber çeşidinin tuz uygulanan bitkilerinde çinko miktarlarında önemli düşüşlerin olduğu, istatiksel olarak en önemli farklılığın uygulama döneminde olduğu tespit edilmiştir. Uygulamalar karşılaştırıldığında, çarliston biber çeşidi tuz uygulamasının 10. gününde kontrol bitkileri ile tuz uygulaması yapılan bitkilerin yapraklarındaki çinko miktarları farkl1lıkları istatistiki olarak önemsiz bulunmuştur. 
Tablo 5. Tuz uygulaması öncesi (0. gün), tuz uygulama dönemi ve geçici stres sonrası dönemde periyodik olarak alınan biber bitkilerinin yapraklarında ölçülen çinko miktarları ( $\mu \mathrm{g} \mathrm{mg}^{-1} \mathrm{~T}$.A.)

\begin{tabular}{|c|c|c|c|c|c|c|c|}
\hline \multirow{2}{*}{ DÖNEM } & \multirow{2}{*}{ PERIYYOT } & \multicolumn{2}{|c|}{ ÇARLİSTON } & \multirow{2}{*}{ P DEĞ. } & \multicolumn{2}{|c|}{ ACI ÇİÇEK } & \multirow{2}{*}{ P DEĞ. } \\
\hline & & KONTROL & $\mathrm{NaCl}$ & & KONTROL & $\mathrm{NaCl}$ & \\
\hline STRES ÖNCESİ & 0.GÜN & $8,68 \pm 1,75 \mathrm{~A}$ & $8,68 \pm 1,75 \mathrm{~A}$ & - & $9,28 \pm 1,85 \mathrm{~A}$ & $9,28 \pm 1,85 \mathrm{~A}$ & - \\
\hline \multirow{2}{*}{$\begin{array}{l}\text { GEÇİCI STRES } \\
\text { UYGULAMA } \\
\text { DÖNEMİ }\end{array}$} & 10. GÜN & $6,59 \pm 1,03 \mathrm{AB}$ & $6,90 \pm 1,46 \mathrm{AB}$ & 0,7810 & $5,86 \pm 0,57 \mathrm{AB} \mathrm{b}$ & $6,93 \pm 0,26 \mathrm{AB}$ a & 0,0433 \\
\hline & 20. GÜN & $4,00 \pm 0,51 \mathrm{C} \mathrm{b}$ & $5,4 \pm 0,45 \mathrm{BC}$ a & 0,0249 & $3,92 \pm 1,09 \mathrm{~B} \mathrm{~b}$ & $5,01 \pm 0,62 \mathrm{BC} \mathrm{a}$ & 0,2089 \\
\hline \multirow{2}{*}{$\begin{array}{l}\text { GEÇİCI STRES } \\
\text { SONRASI } \\
\text { DÖNEM }\end{array}$} & 10. GÜN & $5,16 \pm 1,17 \mathrm{BC} \mathrm{a}$ & $3,81 \pm 0,42 \mathrm{C} \mathrm{b}$ & 0,1335 & $5,49 \pm 1,38 \mathrm{AB}$ & $4,20 \pm 0,51 \mathrm{C}$ & 0,2057 \\
\hline & 20. GÜN & $3,75 \pm 1,10 \mathrm{C}$ & $3,93 \pm 0,81 \mathrm{C}$ & 0,8315 & $3,86 \pm 0,71 \mathrm{~B} \mathrm{~b}$ & $5,94 \pm 2,22 \mathrm{BC} \mathrm{a}$ & 0,1990 \\
\hline \multicolumn{2}{|c|}{ P DEĞERİ } & 0,0025 & 0,0015 & - & 0,0017 & 0,0082 & - \\
\hline
\end{tabular}

Aynı sütunda aynı büyük harfi alan ortalamalar arasındaki fark $\mathrm{P} \leq 0.05$ 'e göre önemsizdir. Aynı satırda aynı çeşidin aynı küçük harfi alan ortalamalar arasındaki fark $\mathrm{P} \leq 0.05$ 'e göre önemsizdir.

Fakat 20. gün sonunda çinko miktarları bakımından farklılıkların önemli olduğu dikkati çekmektedir. Acı biber çeşidinde uygulamalar arası karşılaştırılma yapıldığında çinko miktarlarında istatiksel olarak en önemli farklılığın geçici stres sonrası dönemin 10 . gününde olduğu tespit edilmiştir.

\subsubsection{Yapraklardaki Mn iyonu miktarında meydana gelen değişimler}

Dönemler boyunca periyodik olarak alınan bitkilerin yapraklarında belirlenen mangan miktarları Tablo 6. 'da verilmiştir.

Tablo 6. Tuz uygulaması öncesi (0. gün), tuz uygulama dönemi ve geçici stres sonrası dönemde periyodik olarak alınan biber bitkilerinin yapraklarında ölçülen mangan miktarları $\left(\mu \mathrm{g} \mathrm{mg}^{-1}\right.$ T.A.)

\begin{tabular}{|c|c|c|c|c|c|c|c|}
\hline \multirow{2}{*}{ DÖNEM } & \multirow{2}{*}{ PERIYYT } & \multicolumn{2}{|c|}{ ÇARLISTON } & \multirow{2}{*}{ P DEĞ. } & \multicolumn{2}{|c|}{ ACI ÇİÇEK } & \multirow{2}{*}{ P DEG } \\
\hline & & KONTROL & $\mathrm{NaCl}$ & & KONTROL & $\mathrm{NaCl}$ & \\
\hline STRES ÖNCESİ & 0.GÜN & $36,84 \pm 3,91 \mathrm{~B}$ & $36,84 \pm 3,91 \mathrm{~B}$ & - & $36,53 \pm 3,50 \mathrm{~A}$ & $36,53 \pm 3,50 \mathrm{~A}$ & - \\
\hline \multirow{2}{*}{$\begin{array}{l}\text { GEÇİCİ STRES } \\
\text { UYGULAMA } \\
\text { DÖNEMİ }\end{array}$} & 10. GÜN & $30,67 \pm 1,28 \mathrm{C}$ & $27,85 \pm 4,12 \mathrm{~B}$ & 0,3214 & $23,29 \pm 3,65 \mathrm{~B}$ & $26,73 \pm 4,04 \mathrm{~B}$ & 0,3357 \\
\hline & 20. GÜN & $19,14 \pm 2,57 \mathrm{D} \mathrm{b}$ & $37,50 \pm 4,78 \mathrm{~A} \mathrm{a}$ & 0,0043 & $28,50 \pm 1,23 \mathrm{AB}$ a & $17,15 \pm 1,31 \mathrm{C} \mathrm{b}$ & 0,0004 \\
\hline \multirow{2}{*}{$\begin{array}{l}\text { GEÇİCİ STRES } \\
\text { SONRASI } \\
\text { DÖNEM }\end{array}$} & 10. GÜN & $21,16 \pm 1,98 \mathrm{D}$ & $24,55 \pm 4,40 \mathrm{~B}$ & 0,2913 & $27,17 \pm 9,46 \mathrm{AB}$ & $22,81 \pm 2,57 \mathrm{BC}$ & 0,4842 \\
\hline & 20. GÜN & $43,41 \pm 4,61 \mathrm{~A} \mathrm{a}$ & $26,18 \pm 4,04 \mathrm{~B} \mathrm{~b}$ & 0,0083 & $19,61 \pm 3,92 \mathrm{~B} \mathrm{~b}$ & $33,79 \pm 3,52 \mathrm{~A} \mathrm{a}$ & 0,0096 \\
\hline \multicolumn{2}{|c|}{ P DEĞERİ } & 0,0000 & 0,0090 & - & 0,0232 & 0,0001 & - \\
\hline
\end{tabular}

Aynı sütunda aynı büyük harfi alan ortalamalar arasındaki fark $\mathrm{P} \leq 0.05$ 'e göre önemsizdir. Aynı satırda aynı çeșidin aynı küçük harfi alan ortalamalar arasındaki fark $\mathrm{P} \leq 0.05$ 'e göre önemsizdir.

Çarliston ve acı çiçek biber çeşidinin gerek kontrol bitkilerinde ve gerekse tuz uygulanan bitkilerin yapraklarında belirlenen mangan içeriklerinin dönemsel olarak istatistiksel anlamda önemli farklılıkların olduğu belirlenmiştir. Çarliston biber çeşidinin tuz uygulanan bitkilerinde özellikle geçici stres sonrası dönemin 10. gününde Mn miktarlarında düşüşün olduğu fakat bunun istatiksel olarak önemli olduğu tespit edilmiştir. Ac1 çiçek biber çeşidinin tuz uygulanan bitkilerinde mangan miktarlarında önemli düşüşlerin olduğu tespit edilmiştir. Acı biber çeşidinde Mn miktarları bakımından istatiksel olarak önemli farklılıkların olduğu tespit edilmiştir. Uygulamalar karşılaştırıldığında, çarliston biber çeşidi tuz uygulaması ve geçici stres sonrası dönemin 10 . gününde kontrol bitkileri ile tuz uygulaması yapılan bitkilerin yapraklarında ki mangan miktarları istatistiki olarak önemsiz bulunmuştur. Fakat uygulama dönemi ve geçici stres sonrası dönemin 20. günü sonunda mangan miktarları bakımından farklılıkların önemli olduğu dikkati çekmektedir. Acı biber çeşidinde uygulamalar arası karşılaştırılma yapıldığında mangan miktarlarında istatiksel olarak en önemli farklılığın uygulama dönemi ve geçici stres sonrası dönemlerin 20. gününde olduğu tespit edilmiştir.

\section{TARTIŞMA}

Irshad ve ark. [20], Lacerda ve ark. [21], Cavalcanti ve ark., [22], Üzal [15], Üzal ve Yaşar [16]; Şevgin Zirek
[23], Öztaş [24], Yıldırım [25] gibi araştırıcılar tuz stresi altındaki bitkilerin gelişiminin olumsuz şekilde etkilendiğini rapor etmişlerdir. Çalışmamızda, her iki biber çeşidinde de tuz stresinin bitki gelişimi üzerine olumsuz etkisinin olduğu görülmüştür. Geçici stres sonrası döneme geçildiğinde ise özellikle çarliston biber çeşidinde 20. günde kontrole en yakın değerlerin ölçüldüğü, hatta stress sonrası bitki gelişimi 20. günde 10. güne göre neredeyse iki katına çıkmıştır. Çarliston biber çeşidinin geçici stres sonrası dönemin 20. gününde bitki gelişiminin toparlayabildiği tespit edilmiştir. $\mathrm{Bu}$ veriler göz önüne alındığında tuz stresinden her iki biber çeşidinin de etkilendiği fakat geçici stres sonrası dönemde çarliston biber çeşidinde daha erken iyileşmelerin olduğu görülmüştür. Acı çiçek biber çeşidi ise metabolik aktiviteyi kontrol altında tutabilmek için bitki büyümesini sınırlandırarak bitkiyi kontrol edebilecek seviyede tutmuş olabileceği kanaatine varılmıştır. Geri kazanım sürecinde stres ortamı olmadığından dolayı bitkiler generatif fazdan vegetatif faza geçmiş bu nedenle bitki gelişimlerinde iyileşmelerin olduğu görülmüştür.

Tuzlu topraklarda yetişen bitkilerde mikro (Fe, $\mathrm{Zn}, \mathrm{Mn}$, ve $\mathrm{Cu}$ ) besin elementlerinin çözünürlükleri ve taşınımları zor olduğu için bu besin elementlerinin eksiklikleri görülür. Ancak bu eksiklikler, bitki türü, bitki dokusu, tuzluluk seviyesi ve çevresel koşullara göre farklılık gösterir. Böylece tuz stresinden dolayı bitkilerin türüne 
bağlı olarak mikro element alınımları artar ya da azalır [26]. Tuz stresine tepki olarak bazı bitkilerde $\mathrm{Fe}, \mathrm{Zn}, \mathrm{Cu}$, $\mathrm{Mn}$ ve $\mathrm{Mg}$ gibi mikro besin maddelerinin alınımlarında artışların olduğunu bazı araştırıcılar belirtmişlerdir [27, 28, 29, 30, 31, 12, 32]. Y1ldırım [25] biber bitkisinde yaptığı çalışmada $\mathrm{Fe}, \mathrm{Mn}, \mathrm{Zn}$, ve $\mathrm{Cu}$ elementlerinin alımının tuz stresi altında arttığını bildirmiş bunun sebebini bitkilerin tuz stresine bir tür tepkisi olarak belirtmiştir. Yine Şevgin Zirek [23], biber bitkisinde tuz stresi üzerine magnezyumun etkilerini araştırdığı çalışmada tuz stresi altındaki bitkilerin $\mathrm{Mn}, \mathrm{Zn}$, ve $\mathrm{Cu}$ elementlerinin alımının kontrol bitkilerine göre arttığını belirtmiştir. Ayrıca Shiyab [33] su kültüründe farklı tuz konsantrasyonlarını uyguladığı acı biber bitkisinin mikro element içeriklerini araştırdığ 1 çalışmada kontrole gore bitkilerin $\mathrm{Fe}$ miktarının düştüğünü, $\mathrm{Mn}, \mathrm{Zn}$, ve $\mathrm{Cu}$ miktarlarının arttığını, Cornillon ve Palloix [34] ise su kültüründe biber çeşitlerine farklı tuz konsantrasyonlarını uyguladığı çalışmada ise tuz stresi uygulanan bitkilerin kök ve yapraklarında $\mathrm{Zn}$ konsantrasyonlarının arttığını tespit etmişlerdir. Yaptığımız çalışmadan da bu bilgileri destekler nitelikte, bitki yapraklarında tuz uygulama döneminde $\mathrm{Fe}, \mathrm{Zn}, \mathrm{Mn}$ konsantrasyonlarında artışların olduğu belirlenmiştir. Mikro besin elementlerinin tuz stresi altındaki alımlarında yukarıda bahsettiğimiz araştırıcıların belirttiği gibi, tuza tepki olarak bu elementlerin alımında kontrole göre artışlar olduğu kanaatine varılmıştır.

\section{TEŞEKKÜR}

$\mathrm{Bu}$ makale Van Yüzüncü Yıl Üniversitesi, Bilimsel Araştırma Projeleri Başkanlığı tarafından desteklenen (Proje no: FYL-2018-7594) yüksek lisans tezinden üretilmiştir. Destekleri için teşekkür ederiz.

\section{KAYNAKLAR}

[1] Yahya A. Responses to Soil of Sesame (Sesamum indicum L.) and Sugar Beet (Beta vulgais L.). Doctoral thesis, Uppsala; 1998.

[2] Quamme HA, Stushnoff C. Resistance to Enviromental Stress. "In Methods in Fruit Breeding" (J.N.Moore.J. Janick.eds.). Purdue Univ. Press. West Lapayette, 1983; 242-266.

[3] Tal M. Selection for Stress Tolerance. In 'Handbook of Plant Cell Culture, Volume 1", (D.E. Evans, W.R. Sharp, P.V. Ammirato, Y. Yamada, eds.), Collier Macmillan Publishers, London, 1983;461-487.

[4] Munns R, Termaat A. Whole-plant responses to salinity. Aust. J. Plant Physiol., 1986; 13: 143-160.

[5] Brugnoli E., Lauteri M. Effects of salinity on stomatal conductance, photosynthetic capacity, and carbon isotope discrimination of salt-resistant (Gossypium hirsutum L.) and salt-sensitive (Phaseolus vulgaris L.) C3 non-halophytes. Plant Physiology, 1991; 95, 628-635.

[6] Munns R, Tester M. Mechanisms of salinity tolerance. Annual Review of Plant Biology, 2008; 59, 651- 681.

[7] Víllora G, Moreno D A, Pulgar G, Romero L. Yield improvement in zucchini under salt stress: determining micronutrient balance. Scientia Horticulturae, 2000; 86(3): 175-183.

[8] Bohra JS, Döffling K. Potassium nutration of Rice (Oryza sativa L.) Varieties under $\mathrm{NaCl}$ salinity. Plant and Soil, 1993;152: 299-303.

[9] Yaşar F. Tuz Stresi Altındaki Patlıcan Genotiplerinde Bazı Antioksidant Enzim Aktivitelerinin Invitro ve In Vivo Olarak İncelenmesi. (doktora tezi, basılmamış). Yüzüncü Y1l Üniversitesi Fen Bilimleri Enstitüsü, 2003; Van.

[10] Yasar F, Uzal O, Tufenkci S, Yildiz K. Ion accumulation in different organs of green bean genotypes grown under salt stres. European Journal of Horticultural Science, 2006; 71: 169-172.

[11] Y1ldız K, Üzal Ö, Y1lmaz H. Consequences of $\mathrm{NaCl}$ Salinity on Growth and Iion Accumulation in Selected Strawberry Cultivars, European Journal of Horticultural Science, 2008; 73(2):69-72.

[12] Üzal Ö, Yildiz K. Changes in Micronutrients Cholophyll Contents and Plant Growth of Some Strawberry Cultivars (Fragaria $x$ ananassa L.) under Salt Stress. Yüzüncü Y1l Üniversitesi Tarım Bilimleri Dergisi, 2013; 23(2), 76-82.

[13] Levitt J. Responses of Plants to Environmental Stresses. 2nd ed. Academic Pres, New York, 1980;2: 607.

[14] Daşgan HY, Koç S, Ekinci B, Aktaş H, Abak K. Bazı Fasülye Ve Börülce Genotiplerinin Tuz Stresine Tepkileri. Alatarım, 2006; 5 (1): 23-31.

[15] Üzal, Ö. Tuz Stresi Altında Yetiştirilen Bazı Çilek Çeşitlerinde Jasmonik Asitin Bitki Gelişimi ve Antioksidant Enzim Aktiviteleri Üzerine Etkisi. (Doktora Tezi). Yüzüncü Y1l Üniversitesi. Fen Bilimleri Enstitüsü, Van; 2009.

[16] Üzal Ö, Yaşar, F. Karpuz Genotiplerinde [Citrullus lanatus (Thunb.) Mansf.] Tohum ve Fide Yaprak Özellikleri ile Tuz Toleransı Arasındaki İlişkinin Belirlenmesi, Türkiye Tarımsal Araştırmalar Dergisi, 2017; 4 (3): 259-267.

[17] Hoagland DR, Arnon DI. The water culture method for growing plants without soil. Circ.Calif. Agr. Exp. Sta., 1938; 347-461.

[18] Kacar B. Toprak Analizleri. Ankara Üniversitesi Ziraat Fakültesi Eğitim, Araştırma ve Geliştirme Vakfı Yayınları: 1994; 3, Ankara, 703s.

[19] Taleisnik E, Peyran G, Arias C. Respose of Chlorisgayana Cultivars to Salinity. 1. Germination and Early Vegetatif Growth.Tropical Grassland, 1997; 31: 232-240.

[20] Irshad M, Yamamoto S, Eneji AE, Endo T, Hona T. Urea and Manure Effect on Growth and Mineral Contents of Maize Under Saline Conditions. J Plant Nutrit, 2002; 25(1): 189- 200

[21] Lacerda CF, Cambraia J, Oliva M A, Ruiz HA. Changes in growth and in solute concentrations in sorghum leaves and roots during salt stress recovery. Environmental and Experimental Botany, 2005; 54(1): 69-76.

[22] Cavalcanti FR, Lima JPMS, Ferreira-Silva SL, Viégas RA, Silveira JAG. Roots and leaves display contrasting oxidative response during salt stress and 
recovery in cowpea. Journal of plant physiology, 2007; 164(5): 591-600.

[23] Şevgin Zirek N. Biber Bitkisinde Tuz Stresi Üzerine Magnezyumun Etkileri. Yüzüncü Y1l Üniversitesi Fen Bilimleri Enstitüsü Bahçe Bitkileri Anabilim Dalı, Van, 46-47s; 2017.

[24] Öztaş Ö. Tuz Stresi Altındaki Biber Bitkisine Potasyum Uygulamalarının Etkisinin Araştırılması. Yüzüncü Y1l Üniversitesi Fen Bilimleri Enstitüsü Bahçe Bitkileri Anabilim Dalı, Van, 53s; 2018.

[25] Yıldırım O. Tuz Stresi Altındaki Biber Bitkisine Kalsiyum Uygulamalarının Etkisinin Araştırılması. Yüzüncü Y1l Üniversitesi Fen Bilimleri Enstitüsü Bahçe Bitkileri Anabilim Dalı, Van, 74 s; 2019.

[26] Page A, Chang A, Adriano D. Deficiencies and toxicities of trace elements. Agric Salinity Assess Manage., 1990;71: 138-160.

[27] Alam SM. Nutrient Uptake by Plants Under Stress Conditions. Handbook of Plant and Crop Stress, 1999; 2: 285-313.

[28] Moreno DA, Pulgar G., Romero L. Yield improvement in zucchini under salt stress: determining micronutrient balance. Scientia Horticulturae 2000; 86(3): 175-183.

[29] Turhan E, Eriş A.Changes of Micronutrients, Dry Weight, and Chlorophyll Contents in Strawberry Plants Under Salt Stress Conditions, Communications in Soil Science and Plant Analysis, 2005; 36: 1021-1028.

[30] Tunçtürk M, Yaşar F, Tunçtürk R. Effect of salinity stress on plant green weight and nutrient value of soybean (Glycine max L. merrill) cultivars, Asian Journal of Chemistry, 2009; 21, 1481-1489.

[31] Tunçtürk M, Tunçtürk R, Yildirim B, Ciftci V. Changes of micronutrients, dry weight and plant development in canola (Brassica napus L.) cultivars under salt stress, African Journal of Biotechnology, 2011; 10, 3726-3730.

[32] Yaşar F, Üzal Ö, Yaşar Ö. Investigation of Micro Element Intake of Potassium $\left(\mathrm{K}^{+}\right)$and Salt Stress Applied Pepper Plants, International Journal of Scientific \& Technology Research, 2018; 7, 131134.

[33] Shiyab S. Effects of $\mathrm{NaCl}$ application to hydroponic nutrient solution on macro and micro elements and protein content of hot pepper (Capsicum annuum L.), Journal of Food, Agriculture \& Environment, 2011; 9 (2) 350-356.

[34] Cornillon P, Palloix P. Influence of sodium chloride on the growth and mineral nutrition of pepper cultivars. Journal of Plant Nutrition, 1997; 20 (9): 1085-1094. 